\title{
Advances in thromboprophylaxis in trauma patients, based on current guidelines and research
}

\author{
Wojciech Grodzicki', Piotr Flis' ${ }^{1}$, Przemysław Sławiński', Piotr Piech ${ }^{2,3}$, Paweł Polak ${ }^{3}$, Piotr Walus ${ }^{1}$, \\ Dawid Merkiel', Małgorzata Neścior ${ }^{4}$, Paweł Obierzyński ${ }^{4}$ \\ 1 Orthopaedics and Traumatology Research Group, Department of Orthopaedics and Traumatology, Medical University, \\ Lublin, Poland \\ ${ }^{2}$ Department of Human Anatomy, Medical University, Lublin, Poland \\ ${ }^{3}$ Department of Orthopaedics and Traumatology, Medical University, Lublin, Poland \\ ${ }^{4}$ Human Anatomy Research Group, Department of Human Anatomy, Medical University, Lublin, Poland
}

Grodzicki W, Flis P, Sławiński P, Piech P, Polak P, Walus P, Merkiel D, Neścior M, Obierzyński P. Advances in thromboprophylaxis in trauma patients based on current guidelines and research. Med Og Nauk Zdr. 2018; 24(3): 158-161. doi: 10.26444/monz/93196

\section{Abstract}

Introduction. Thromboprophylaxis remains a significant element in the operative and non-operative treatment of trauma patients due to high risk of thromboembolic incidents. This problem concerns a major part of trauma patients.

Objective. The aim of the study is to review and evaluate the efficacy of the pharmacological and non-pharmacological methods of venous thromboembolic (VTE) prophylaxis.

Brief state of knowledge. There are a few pharmacological methods of VTE prevention, such as: unfractionated heparin (UFH), low molecular weight heparin (LMWH), vitamin K antagonists (VKA), factor Xa inhibitors and direct thrombin Inhibitor. There are also a couple of non-pharmacological methods: intermittent pneumatic compression and graduated compression stockings. The choice of method should be guided by the type of trauma, patient's health status, and potential contraindications for other methods of prophylaxis.

Methods. The authors analyzed recent guidelines and research using the most up-to-date sources. The types of traumas were categorized, and a summary compiled of the best way of VTE prophylaxis for each type of trauma. Recommended methods were also rated with the risk of VTE and haemorrhage.

Conclusions. The conclusions show that there are still too few studies and the guidelines extant are unambiguous (ambiguous?). Improvment must be sought for in thromboprophylaxis and toward defining uniform guidelines. Due to the large number of surgeries in the treatment of traumas, there is a need to retain all the guidelines in one article. Every operation is connected with high risk of venous thromboembolism, therefore optimal prophylaxis is crucial.

\section{Key words}

tromboprophylaxis, traumatic patients, acute pulmonary embolism, venous thromboembolism

\section{INTRODUCTION}

Venous thromboembolism consists of deep vein thrombosis (DVT) and pulmonary embolism (PE), which if not treated, can lead to death, the avoidance of which is crucial during the treatment of trauma patients. The surgeries and invasive diagnostic methods are associated with a high risk of VTE. The PE is a compelling clinical issue with a significant mortality of up to $30 \%$. Pulmonary emboli usually arise from deep veins in lower extremities; however, they can also arise rarely from veins in the upper extremities and pelvic veins. The emboli travel to the lungs and can attach to the bifurcation of the main pulmonary artery, or become stuck in one of the lobar branches. Mortality of PE is high. It is claimed that during autopsy about $30 \%-45 \%$ of patients had been diagnosed with pulmonary embolism before death. About $10 \%$ of patients die suddenly due to PE, one of the three most common diseases of the cardiovascular system[1].

Address for correspondence: Piotr Piech, Department of Human Anatomy, Department of Orthopedics and Traumatology, Medical University, Jaczewskiego 4, 20-090 Lublin, Poland

E-mail: ppiotr.md@gmail.com

Received: 27 May 2018; Accepted: 11 July 2018
Despite numerous methods, this disease is still diffuculty to diagnose. Increasing the concentration of $\mathrm{D}$-dimer is used in the diagnosis, but most commonly, ultrasound examination is used. Every trauma patient should be treated with VTE prophylaxis [2].

\section{OBJECTIVE}

Venous thromboembolism can be a life-threatening disease; it is the third leading cause of cardiovascular-associated death worldwide [3]. It is a very common issue among orthopaedic society and the aim of the study was to examine it in detail, to research studies from online databases that focus on VTE after trauma, review and compare with Polish, British and American guidelines.

Due to the risk of a serious disease after traumas and surgeries there is a need for guidelines and instructions for prophylaxis. This review is based on selected research and guidelines for treatment of common traumas and orthopedic surgeries. It will be useful for matching the best strategy of treatment for patients. 


\section{BRIEF STATE OF KNOWLEDGE}

Risk factors. Over 160 years ago, Rudolf Virchow, a German physician, identified 3 main factors that increase the risk of VTE: venous stasis, changes in blood composition, and endothelium injury that can induce a hypercoagulable state. Although these factors are crucial, they are not the only ones responsible for VTE. It is a well-known fact that immobility, surgeries, bacteraemia, pregnancy, the postpartum period, hormone therapy, varices, dehydration, obesity, age over 40 and thrombophilia are also further risks of VTE [4]. Other studies also add cancer history, inflammatory bowel disease, rheumatic diseases, heart failure, injury, surgery and transfusions of RBC [5]. Many of the aforementioned factors are connected with trauma (immobility, surgeries, bacteraemia) and cause concern among orthopedists. Therefore, knowing these factors, it is essential to choose the best methods of TPX (thromboprophylaxis), either mechanical or pharmacologic, or both at the same time.

There are 3 broad categories of factors which lead to the creation of a blood clot: hypercoagulability, haemodynamic changes, endothelial injury/dysfunction. The most important for orthopedics are haemodynamic changes due to prolonged immobility. Long treatment in a hospital and recovery sometimes demand immobility and being in one position for a long period of time. A few mechanisms lead to platelet activation, which is needed to form a blood clot: connection with exposed collagen and tissue factor encryption, after which a cascade of processes leads to clot formation. This can be achieved through intrinsic and extrinsic pathways of coagulation which is essential to inhibit those processes and prevent excessive formation of blood clots, without causing massive haemorrhages. For this reason, urgent research should be undertaken of this important issue.

Mechanical thromboprophylaxis. Mechanical TPX reduces stasis of the blood in the deep venous system by increasing the blood flow, and the return of the blood to the right ventricle. Pooling of the blood is not the only problem that mechanical TPX lowers, it also reduces microvascular damage of the veins caused by stretching of stasis of the blood in the deep venous system. Mechanical TPX includes anti-embolism stockings (AES), foot impulsed technology (FIT), and intermittent pneumatic compression (IPC). The biggest advantage of using mechanical prophylaxis is the lack of influence on the process of coagulation. Therefore, there is no increased risk of bleeding. However, there are disadvantages, including the high cost, poor compliance, and most importantly, lower efficacy than pharmacological methods. Thus, it is crucial to be well-versed in the patient's history if mechanical TPX is to be applied.

Pharmacological thromboprophylaxis. Pharmacological TPX consists of unfractionated heparin (UFH), low molecular weight heparin (LMWH), vitamin K antagonists (VKA), factor Xa inhibitors and direct thrombin inhibitor. There are also pros and cons for using pharmacological TPX. These pharmaceuticals factors interfere with the process of coagulation, thus they can cause bleedings, which are the main disadvantage of this method. However there are ways to properly verify and administer those medicaments. Fortunately, pharmacological TPX has many advantages that make this method the most commonly used one.
These advantages are efficacy and sufficient compliance, as opposed to compliance in mechanical prophylaxis. UFH is a naturally present anticoagulant which is produced by basophils and mast cells. Unfractionated heparin has limited bioavailability, variable anticoagulant effect, and highly variable anticoagulant response[6]. Thus, according to ACCP guidelines, UFH should not be used alone as TPX in trauma patients[7]. LMWHs are obtained by fractionation or depolymerisation of heparin. Low molecular weight heparins inhibit coagulation enzymes by activating antithrombin. Antithrombin stops coagulation by inhibiting factor $\mathrm{Xa}$, thrombin and also by promoting fibrinolysis through inhibiting PAI-1 (Platelet Activator Inhibitor-1). LMWHs are the most commonly used thromboprophylactic pharmaceuticals due to their reduced protein binding, greater bioavailability and dose-independent clearance which makes LMWHs more predictable without the need of laboratory monitoring[8]. Because of the aforementioned properties, LMWHs are the most effective and widely-used methods of pharmacological thromboprophylaxis. Vitamin $\mathrm{K}$ antagonists, such as warfarin, inhibit the synthesis of clotting factors X, IX, VII and II, thereby stopping the coagulation. VKA have been known for their delayed onset of action, many drug and food interactions, variable anticoagulant effect, problematic reversal, potential, and most importantly, they require laboratory monitoring. That is why, comparied with LMWHs, they are not so commonly and widely used [2].

\section{THROMBOPROPHYLAXIS IN PARTICULAR TYPES OF TRAUMAS}

Pelvic fractures. Fractures of pelvis are associated with a high risk of VTE. They are ratred at ' 5 ' on the Capriani scale (grade 5 and above indicate a high-risk of VTE). Such trauma patients require thromboprophylaxis which should be administered immediately after the injury. In some cases, it can be delayed because of the risk of haemorrhage. An early implementation of DVT prophylaxis in trauma patients is safe and it decreases the risk of DVT[9]. Every case needs to be treated individually. Patients with at high risk should be treated with a low dose UFH. The treatment should be started before the surgery and continued afterwards. A low dose UFH is preferred to other classes of drugs due to a lower risk level of HIT, and because of an easy way of administration. An alternative option is fondaparinux. VKA are not commonly used $b$ ecause their use is difficult and ineffective, due to delayed time of drug reaction, many interactions and lower effectiveness than a low dose UFH. Warfarin is an exception. It can be used in some cases, for instance, acute traumas, patients without any other surgeries planned in the near future, and patients with rehabilitation not shorter than 14 days [10]. Adding mechanical methods can improve the effectiveness of pharmacological treatment, and is most useful in patients with a high risk of VTE. Patients with haemorrhage and with contraindications to pharmacological prophylaxis can be treated only with mechanical methods $[4,5,11]$.

Femoral fractures. Patients with proximal femoral fracture are highly exposed to DVT (46-60\%) and fatal pulmonary embolism (2.5-7.5\%). The risk lingers for up to $2-3$ months after surgery despite using TPX, and joint risk of death within 
3 months is as high as $13 \%$ [5]. Research has shown that $4.8-40 \%$ of trauma patients who did not use TPX, developed DVT symptoms [12]. This is the reason why appropriate thromboprophylaxis in that sort of trauma is crucial, and all patients with femoral fractures should take TPX. Of of all possible methods of pharmacological TPX, the most effective is LMWH because of its quick onset of action and short halflife. According to Tomkowski and Witold, et al., using LMWH is a class A recommendation, while UFH and fondaparinux belong to class B recommendation. Applying mechanical thromboprophylaxis, such as antiembolism stockings (AES), foot impulsed technology (FIT), intermittent pneumatic compression (IPC) should be considered when there are contraindications to using pharmacological TPX (B class recommendation)[4]. If an immediate surgical treatment is not possible, pharmacological or mechanical TPX should be applied as soon as a fracture is diagnosed. According to ACCP recommendations from 2012, prophylaxis should be applied earlier than 12 hours before surgery and 12 hours after surgery at the earliest; this is very important in acute traumas and demands for immediate surgery. Prophylaxis should last for a minimum of 10-14 days[12].

Other lower limb traumas. Plaster splints and plaster casts are often used to treat lower limb injuries, thus it is related to immobilization and leads to higher risk of VTE. The main complication after foot and ankle trauma is DVT, which happens to 1 in 250 patients[13]. In the cohort study by Jose A. Blanco et al., VTE occurs in 35\% of foot and ankle injuries, and in $4.8 \%$ of tendo-achillis (TA) ruptures occur. The $1 \%$ of patients treated for TA rupture was classified as being at high risk of VTE and were given LMWH TPX, of whom 33\% developed a VTE event [14]. According to NICE (National Institute for Health and Care Excellence) 2010 guidelines, pharmacological methods should be considered after individual conversation with a patient[15]. Whereas ACCP guidelines show that VTE prophylaxis should not be used among this group of patients, which is also confirmed in study by Jitendra Mangwani et al. [7, 16]. The Polish Consensus Statement 2017 also does not recommend applying VTE prophylaxis to injured patients who are immobilized by plaster splints and casts (class C recommendation). VTE prophylaxis should be introduced for patients with a moderate and high risk of VTE occurence. LMWH should be used in the case of a lower limb trauma, if the patients are treated by immobilizing a limb in plaster casts or splints, during the immobilization, and after 5-7 days.

Spine trauma. The risk of VTE in patients who are operated as a result of an isolated spine trauma may reach even $10.8 \%$ without TPX and 2.1\% with TPX applied [17]. According to Eskildsen, the risk of VTE is less after spine trauma surgery than after endoprosthetic replacements[18, 19]. NICE guidelines recommend using mechanical methods of VTE prophylaxis in patients after admission, and if they are not receiving any permanent pharmacological prophylaxis nor are in a VTE risk group. As reported by NICE guidelines, pharmacological methods (UFH, LMWH) should be applied to patients with a low risk of bleeding regarding individual risk factors. The therapy should be continued throughout the immobility period (usually 5-7 days)[15]. A study by Sharpe et al. proved that preoperative prophylaxis decreases the risk of PE, and with a low risk of bleeding [20].

\section{CONCLUSIONS}

The presented results of analysis unequivocally show that VTE is a serious and dangerous problem connected with trauma patients. The authors have made a summary of the latest, possible and available research and guidelines which can be helpful during making therapeutic decisions and planning a strategy or methods of treatment. The risk of VTE in patients after trauma is high and is related with dangerous and life-threatening complications. If this disease is left untreated, it will lead to serious complications, such as pulmonary embolism (PE). PE is the result of the narrowing or occlusion of the pulmonary artery or its branches by thrombotic material which most often originate from the deep veins of the lower limbs or pelvis. Untreated, PE develops life-threatening symptoms. and is especially dangerous for elderly patients. Due to the high risk of trauma in elderly patients because of a lot of fractures, there is a need to take special care of this group of patients.

Sometimes, diagnosing PE is hard due to a lack of specific marker and non- specific symptoms; therefore, it is very important to carefully choose the right prophylactic method. Due to different types of traumas, condition and age of patients, there are different guidelines for prophylaxis. There is no ideal prophylaxis of VTE. This results in a serious necessity to conduct new research and define uniform guidelines. This disease can induce serious results, so each case needs to be individually treated. Due to the high risk of haemorrhage, especially in pelvic traumas, treatment is delayed. Some research has shown that early implementation of DVT prophylaxis is safe and decreases the risk of DVT [9]. This issue needs more research and guidelines based on the research. Non- operative traumas, especially pelvic fractures, demand clear guidelines, but owadays there are no treatment strategies strictly dedicated to them. The literature focuses on individual groups of drugs rather than on a more holistic view, like types of traumas or how to merge different ways of treatment.

Another problem which doctors have to face are patients who suffer from comorbidities, such as atrial fibrillation. In such cases, treatment should be consulted with other specialists, for instance, with a cardiologist. People with other diseases are common in society, especially elderly patients. Sometimes this group of society suffers from varicose veins, which leads to DVT. The treatment for them must be carefully matched due to taking antithrombotic drugs in the past and at present. They should be carefully taken care of during the treatment. Starting the prophylaxis before a surgery is important to achieve a therapeutic goal. Judgment of the appropriate moment to get started is sometimes challenging, and depends on the type of trauma, patient's health, risk of VTE and haemorrhage, and the type of drug which is planned to be used. The group of aged patients is connected with the high risk of VTE after traumas due to the necessity of longer immobilization. They demand special care.

Progress in pharmaceutical science provides has provided new groups of drugs, e.g rivaroxaban, and there is a possibility thatin the future it will be used in VTE prophylaxis. Mechanical methods of treatment should also be taken into consideration although these methods are often underappreciated. In the future, these devices will be more efficient and it is possible that their use will be standard in VTE prophylaxis. 


\section{REFERENCES}

1. Bĕlohlávek J, Dytrych V, Linhart A. Pulmonary embolism, part I: Epidemiology, risk factors and risk stratification, pathophysiology, clinical presentation, diagnosis and nonthrombotic pulmonary embolism. Exp Clin Cardiol. 2013; 18(2): 129-38.

2. Jaff MR, McMurtry MS, Archer SL et al. Management of massive and submassive pulmonary embolism, iliofemoral deep vein thrombosis, and chronic thromboembolic pulmonary hypertension. Circulation. 2011; 123(16): 1788-1830.

3. Mackman N. Triggers, targets and treatments for thrombosis. Nature. 2008; 451(7181): 914-918.

4. Tomkowski W, Kuca P, Urbanek T et al. Venous thromboembolism - recommendations on the prevention, diagnostic approach and management. The 2017 Polish Consensus Statement. Acta Angiol. 2017; 23(2): 83-87.

5. Paydar S, Sabetian G, Khalili H et al. Management of Deep Vein Thrombosis (DVT) Prophylaxis in Trauma Patients. Bull Emerg Trauma. 2016; 4(1): 1-7.

6. Ruiz AJ, Hill SL, Berry RE. Heparin, deep venous thrombosis, and trauma patients. Am J Surg. 1991; 162(2): 159-62.

7. Falck-Ytter Y, Francis C W, Johanson N M et al. Prevention of VTE in orthopaedic surgery patients. Antithrombotic therapy and prevention of thrombosis, 9th ed: American college of chest physicians. Evidencebased clinical practice guidelines. Chest. 2012; 141(2 Suppl): e278Se325S.

8. Ganzer D, Gutezeit A, Mayer G. Potentials risks in drug prevention of thrombosis --low-molecular-weight heparin versus standard heparin. Z Orthop Ihre Grenzgeb. 1999; 137(5): 457-61.

9. Jehan F, O'Keeffe T, Khan M et al. Early thromboprophylaxis with Low-Molecular-Weight heparin is safe in patients with pelvic fracture managed nonoperatively. J Surg Res. 2017; 219: 360-365.

10. Chana-Rodríguez F, Pérez Mañanes R, Rojo-Manaute J et al. Methods and Guidelines for Venous Thromboembolism Prevention in Polytrauma Patients with Pelvic and Acetabular Fractures. Open Orthop J. 2015; 9: 313-320.
11. Kadu V. Prevention and Management of Thrombo-Embolism in Pelvi Acetabular Fractures. J Orthop Complic. 2016; 1(1): 26-28.

12.Zee AAG, van Lieshout K, van der Heide $M$ et al. Low molecular weight heparin for prevention of venous thromboembolism in patients with lower-limb immobilization. Cochrane Database Syst Rev. 2017; 8: CD006681

13. Selby R, Geerts WH, Kreder HJ et al. Symptomatic venous thromboembolism uncommon without thromboprophylaxis after isolated lower-limb fracture: the knee-to-ankle fracture (KAF) cohort study. J Bone Jt Surg Am. 2014; 96(10): 83-93.

14. Blanco JA, Slater G, Mangwani J. A Prospective Cohort Study of Symptomatic Venous Thromboembolic Events in Foot and Ankle Trauma: The Need for Stratification in Thromboprophylaxis? J Foot Ankle Surg. 2018; 57(3): 484-488.

15. Venous Thromboembolism: reducing the risk: reducing the risk of venous thromboembolism (deep vein thrombosis and pulmonary embolism) in patients admitted to hospital. NICE https://www.nice. org.uk/guidance/cg92 (access: 2018.05.29).

16. Mangwani J, Sheikh N, Cichero $M$ et al. What is the evidence for chemical thromboprophylaxis in foot and ankle surgery? Systematic review of the English literature. Foot(Edinb). 2015; 25(3): 173-178.

17.Zeeshan M, Khan M, O`Keeffe T et al. Optimal timing of initiation of thromboprophylaxis in spine trauma managed operatively: a nationwide propensity matched analysis of trauma quality improvement program. J Trauma Acute Care Surg. 2018.

18. Glotzbecker MP, Bono CM, Wood KB et al. Thromboembolic disease in spinal surgery: a systematic review. Spine (Phila Pa 1976). 2009; 34(3): 291-303.

19. Eskildsen SM, Moll S, Lim MR. An Algorithmic Approach to Venous Thromboembolism Prophylaxis in Spine Surgery. J Spinal Disord Tech. 2015; 28(8): 275-81

20. Sharpe JP, Gobbell WC, Carter AM et al. Impact of venous thromboembolism chemoprophylaxis on postoperative hemorrhage following operative stabilization of spine fractures. J Trauma Acute Care Surg. 2017; 83(6): 1108-1113.

\title{
Postępy w profilaktyce przeciwzakrzepowej u pacjentów po urazach w oparciu o aktualne wytyczne i badania
}

\author{
I Streszczenie \\ Wprowadzenie. Profilaktyka przeciwzakrzepowa stanowi istotny element operacyjnego i nieoperacyjnego leczenia \\ pacjentów urazowych ze względu na wysokie ryzyko wystąpienia choroby zakrzepowo-zatorowej. \\ Cel pracy. Celem pracy jest przegląd i ocena skuteczności farmakologicznych i niefarmakologicznych metod profilaktyki \\ zakrzepowo-zatorowej. \\ Skrócony stan wiedzy. Na rynku dostępnych jest kilka leków stosowanych w profilaktyce zakrzepowo-zatorowej, takich jak: \\ niefrakcjonowana heparyna, heparyna drobnocząsteczkowa, antagonisty witaminy K, inhibitory czynnika Xa i bezpośrednie \\ inhibitory trombiny. Dostępnych jest również kilka metod niefarmakologicznych: przerywana kompresja pneumatyczna \\ i pończochy o stopniowanym ucisku. Wybór tych metod powinien podyktowany być typem urazu, stanem zdrowia pacjenta \\ oraz potencjalnymi przeciwskazaniami dla innych metod profilaktyki. \\ Metody. Autorzy poddali analizie aktualne wytyczne i badania naukowe dotyczące omawianej tematyki, korzystając \\ z najnowszych źródeł. Następnie omówili dostępne środki stosowane w profilaktyce zakrzepowo-zatorowej, po czym opisali \\ najnowsze dostępne metody profilaktyki stosowane w przypadku poszczególnych urazów. \\ Wnioski. Wnioski z tej pracy pokazują, iż wciąż jest zbyt mało badań naukowych oraz wytyczne pozostają niejednoznaczne. \\ Należy ciągle dążyć do ulepszenia profilaktyki zakrzepowo-zatorowej i ujednolicenia wytycznych. Ze względu na mnogość \\ operacji zaopatrujących urazy należy skupić różne wytyczne w jednym artykule. Każda operacja łączy się z dużym ryzykiem \\ choroby zakrzepowo-zatorowej, a zatem odpowiednia profilaktyka jest kluczowa.
}

\section{Słowa kluczowe}

profilaktyka przeciwkrzepliwa, pacjenci urazowi, zatorowość płucna, żylna choroba zakrzepowo zatorowa 